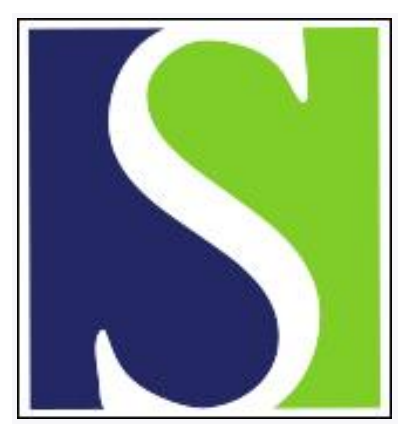

Scand J Work Environ Health 2003;29(2):134-142

https://doi.org/10.5271/sjweh.715

Issue date: Apr 2003

What employees with rheumatoid arthritis, diabetes mellitus and hearing loss need to cope at work

by Detaille SI, Haafkens JA, van Dijk FJH

Affiliation: Coronel Institute for Occupational and Environmental Health, Academic Medical Center, University of Amsterdam, PO Box 22700, 1100 DD Amsterdam, The Netherlands.

The following articles refer to this text: 2009;35(4):261-281;

2011;37(4):288-297; 2019;45(1):73-81

Key terms: chronic disease; concept mapping; coping at work; diabetes mellitus; employee; employment; hearing loss; patient's perspective; rheumatoid arthritis; work disability

This article in PubMed: www.ncbi.nlm.nih.gov/pubmed/12718499 


\title{
What employees with rheumatoid arthritis, diabetes mellitus and hearing loss need to cope at work
}

\author{
by Sarah I Detaille, MA, ${ }^{1,2}$ Joke A Haafkens, PhD, ${ }^{1}$ Frank JH van Dijk MD'
} Detaille SI, Haafkens JA, van Dijk FJH. What employees with rheumatoid arthritis, diabetes mellitus and hearing
loss need to cope at work. Scand J Work Environ Health 2003;29(2):134-142.

Objectives This study attempted to determine factors that help currently employed people with rheumatoid arthritis, diabetes mellitus or hearing loss to continue working.

Methods This was a qualitative study that used three concept-mapping sessions. Sixty-nine participants (rheumatoid arthritis 21, diabetes mellitus 23, and hearing loss 25) were recruited from the patient records of the rheumatology, diabetes, and audiology outpatients of the Academic Medical Center (AMC), Amsterdam, and referrals from occupational physicians and patient associations. An arthritis consultant, a diabetes consultant, and an audiologist screened the patients for the used illness inclusion criteria. A researcher screened the patients for the inclusion criteria of age and work.

Results The main factors enabling employees to continue working were ability to cope with the illness, support from management and colleagues, adequate work conditions, support of patient organizations and society, support of medical professionals and facilities, and benefits. The three groups of employees rated the priority of these factors differently. For the employees with rheumatoid arthritis, the support of management was the most important, followed by self-acceptance, self-efficacy, and professional advice on how to cope at work. For those with diabetes mellitus, self-acceptance, self-care, and support from management, colleagues and health professionals were the most important. For employees with hearing loss, being well informed about hearing equipment, reimbursement, and self-acceptance were the most important. A topic list was developed that can be used by health professionals as a guideline for exploring the work-related problems of patients with a chronic disease.

Conclusions The results provide an understanding of the needs chronically ill employees have at work and the areas to which health professionals need to pay attention.

Key terms chronic disease, concept mapping, employment, patient's perspective, work disability

At present, one-third of the Dutch working population has at least one chronic illness. Despite improvements in medical treatment, staying well at work and retaining a job are often difficult for this group (1-3). In the past, facilitating employment for working people with a chronic illness was not a key health care activity. However, recognition is growing that a lack of attention to the worklife of chronically ill employees may lead to unnecessary job loss and an increase in the social and financial costs to the individual and the community.
In The Netherlands, medical specialists, general practitioners, and occupational health physicians are beginning to join forces to improve the occupational health care of employees with chronic illnesses (4-5). Initiatives have been taken to develop multidisciplinary guidelines focused on the assessment and management of work-related problems associated with these conditions. Any such steps to improve health care in this sector require the collection of information from the patients themselves. A review of the literature on rheumatoid arthritis, diabetes mellitus, and hearing loss Amsterdam, The Netherlands.

2 Current affiliation: University Medical Center of Nijmegen, The Netherlands.

Correspondence to: Dr JA Haafkens, Coronel Institute for Occupational and Environmental Health, Academic Medical Center, University of Amsterdam, PO Box 22700, 1100 DD Amsterdam, The Netherlands. [E-mail: j.a.haafkens@amc.uva.nl] 
revealed few such studies (6). With respect to rheumatoid arthritis, most studies focused on the expert's evaluation of the patient's functional ability and task performance (7-9). Only one study addressed the perspective of employees with rheumatoid arthritis, the challenges they face at work, and the adaptations they need (10). With respect to hearing loss, some studies focused on social interactions at work, (11) while others only dealt with noise-induced hearing loss (12-15) or registered the effects of early intervention from the doctor's perspective (16). Although there are many studies on work-related problems associated with diabetes mellitus, they do not relate to the patient's experience of working with a chronic illness, but focus on functional and mental abilities (17-21).

At present, there is no detailed information available about the problems and needs of chronically ill employees. For this reason, using concept-mapping sessions to collect information, we performed a qualitative study of how employees with rheumatoid arthritis, diabetes mellitus, or hearing loss perceive their work situation.

\section{Subjects and methods}

Purposeful sampling was used to select three groups of 25 (maximum) patients with rheumatoid arthritis, diabetes mellitus, or hearing loss. Diabetes mellitus and hearing loss were chosen because they have a relatively high prevalence in The Netherlands (22). Rheumatoid arthritis was chosen because many patients with rheumatoid arthritis continue to work (22). The inclusion criteria were as follows: rheumatoid arthritis: being diagnosed with rheumatoid arthritis without permanent work disability (23); diabetes mellitus: being diagnosed with diabetes type 1 or 2; and hearing loss: having a 40 to $80 \mathrm{~dB}$ mean loss at 1,2 , and $4 \mathrm{kHz}$ in the best ear. For each illness, additional inclusion criteria were lack of any other chronic illness that may affect work, having a paid job, and age between 21 and 60 years. An arthritis consultant, a diabetes consultant, and an audiologist screened the patients with respect to the disease inclusion criteria. A researcher screened for the inclusion criteria for employment and age. For rheumatoid arthritis, 61 patients meeting the inclusion criteria were invited to participate in the study. They were selected from the records of the Rheumatology Outpatient Clinic of the Academic Medical Center (AMC) in Amsterdam, occupational physicians, and patients of the Dutch Association for Rheumatoid Arthritis. Twentyone consented to participate (table 1). For diabetes mellitus, 93 patients meeting the inclusion criteria were invited to participate in the study. They were selected from the patient records of the AMC Diabetes Outpatient Clinic. Twenty-three consented to participate in the study (table 1). For hearing loss, 60 patients met the inclusion criteria and wanted to participate in the study. The patients were selected from the patient records of the AMC Audiological Center and had been referred by the Dutch Association of Hearing Loss Patients. An audiologist confirmed that these people met our criteria of moderate or severe hearing loss $(40$ to $80 \mathrm{~dB}$ mean loss at 1,2 and $4 \mathrm{kHz}$ in their best ear). Of the 60 , we selected 25 patients at random and invited them to participate in the study (table 1). The relatively high nonresponse rates for people with rheumatoid arthritis and diabetes mellitus were due to the fact that the conceptmapping sessions were held during the weekend and vacation time. The AMC Medical Ethics Committee approved the study design, and the participants gave their informed consent.

\section{Data collection}

The method known as "concept mapping" was used to gather statements on the problems the participants

Table 1. Characteristics of the participants.

\begin{tabular}{|c|c|c|c|}
\hline Characteristic & $\begin{array}{l}\text { Rheumatoid } \\
\text { arthritis a } \\
(\mathrm{N}=21) \\
(\%)\end{array}$ & $\begin{array}{l}\text { Diabetes } \\
\text { mellitus }{ }^{\mathrm{a}} \\
(\mathrm{N}=23) \\
(\%)\end{array}$ & $\begin{array}{c}\text { Hearing } \\
\text { loss }^{a} \\
(\mathrm{~N}=25) \\
(\%)\end{array}$ \\
\hline Female & 62 & 48 & 64 \\
\hline \multicolumn{4}{|l|}{ Level of education } \\
\hline Lower & 15 & 14 & 23 \\
\hline Middle & 52 & 41 & 35 \\
\hline High & 33 & 45 & 42 \\
\hline \multicolumn{4}{|l|}{ Disease first diagnosed } \\
\hline $0-2$ years ago & 43 & 14 & 20 \\
\hline $2-5$ years ago & 30 & 32 & 5 \\
\hline $5-10$ years ago & 17 & 46 & 0 \\
\hline >10 years ago & 10 & 8 & 75 \\
\hline \multicolumn{4}{|l|}{ Type of job ${ }^{b}$} \\
\hline Light mental work & 52 & 22 & . \\
\hline Heavy mental work & 19 & 26 & . \\
\hline Mental and physical work & 29 & 52 & $\cdot$ \\
\hline Mostly verbal communication & . & . & 56 \\
\hline $\begin{array}{l}\text { Mostly nonverbal communi- } \\
\text { cation }\end{array}$ & . & . & 44 \\
\hline \multicolumn{4}{|l|}{ Work situation after diagnosis } \\
\hline Not changed & 45 & 72 & 56 \\
\hline Fewer hours a week & 25 & 28 & 20 \\
\hline Another job at same company & 20 & 0 & 8 \\
\hline Type of job changed & 10 & 0 & 16 \\
\hline Diabetes mellitus type 1 & . & 46 & . \\
\hline Diabetes mellitus type 2 & . & 54 & . \\
\hline Insulin-dependent & . & 87 & . \\
\hline
\end{tabular}

a Age: rheumatoid arthritis = mean 50 (range 23-65) years, diabetes mellitus = mean 45 (range 41-57) years, hearing loss = mean 49 (range 36-58) years.

b The employees with hearing loss were subdivided in terms of the communication demands of the job. Those with rheumatoid arthritis or diabetes mellitus were subdivided in terms of the physical or nonphysical demands of the job. 


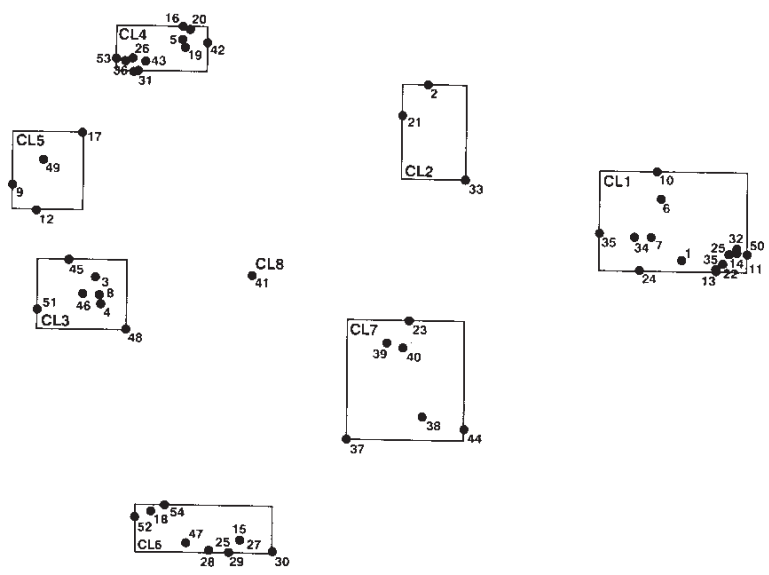

Figure 1. Concept map of the employees with diabetes mellitus.

experienced at work. This method can be used in groups to develop conceptual frameworks to guide planning and evaluation (24). For each chronic condition, a 4-hour concept mapping session was held with a maximum of 25 employees, led by a facilitator.

The participants were first asked to generate statements in a collective group session. This process required a good focus question (24), and therefore the participants were asked to generate statements completing the following sentence: "What a person with rheumatoid arthritis, diabetes mellitus, or hearing loss needs to be able to keep on working is ...." The concept-mapping method requires that statements do not contain multiple messages or are bonded to time and place (25). Therefore, the facilitator encouraged the participants to clarify unfamiliar terms or jargon and helped them to edit their statements if needed. Each statement was typed into a computer by an assistant and printed on a card. Each participant received a stack of cards with the statements and was asked to rate the statements for priority on a Likert scale from 1 to 5 (1 the lowest and 5 the highest priority). The participants then sorted the statements in a logical manner according to themes by forming clusters. Each participant recorded the results of the priority rating and the theme sorting of the statements on a special form. These results were entered into a computer.

\section{Data analysis}

The statements formed the basis of the analysis. First, the arithmetic mean of the priorities assigned to each statement was calculated. This process resulted in a rating list of statements, one for each group of participants. Then, a multidimensional scaling technique (26-28) was used to calculate how often two statements were placed in the same theme by a participant, on the basis of a binary matrix. Then, the individual scores were summed and each statement was represented as a point on a twodimensional scale map (figure 1). This point map graphically represented distances between statements: statements that are frequently placed in the same theme or cluster are located closer to each other than those grouped together less often. Finally, the point map was shown to the participants, and they were asked to name each cluster. All the multidimensional scaling analyses were performed with software called Ariadne (29). Clusters with high-priority statements scored higher. The arithmetic means of the priorities ( $1=$ low priority and $5=$ high priority) have been presented per cluster. To consolidate the results, the clusters produced by each group were compared. Clusters with a similar content were grouped together. The results have been represented in a descriptive meta-matrix (30). To overcome problems of semantics (similar cluster names used by different groups to describe different issues and, conversely, clusters with similar meanings labeled differently), the research team identified clusters with similar meanings across groups. These were then grouped together under appropriate thematic headings.

\section{Results}

The 69 participants produced 172 statements divided into 24 clusters. The top five statements of each cluster are given in the tables, together with the mean priority for each statement (1=low priority, $5=$ high priority) and cluster.

\section{Diabetes mellitus}

The employees with diabetes mellitus produced 54 statements in response to "What an employee with diabetes mellitus needs to be able to keep on working is ...." and sorted them into eight clusters (table 2).

The statements in the first cluster indicated that employees with diabetes mellitus can continue to work with diabetes provided they have accepted the illness and know how to look after themselves at work (eg, to maintain their blood sugar level). Employees need to know their own illness well in order to cope at work. The statements in the second cluster indicated that these employees need to be informed about how to obtain and finance devices. In particular, good equipment was considered important for coping with diabetes at work. The statements in the third cluster showed that the employees felt it important that their colleagues understood and were aware of the symptoms and consequences of diabetes. Thus it is important for employees with diabetes mellitus to be able to communicate with colleagues and management about diabetes, to gain support and to obtain 
Table 2. What an employee with diabetes mellitus needs to be able to keep on working (priority score).

\begin{tabular}{|c|c|c|}
\hline Cluster & Mean & Statement \\
\hline $\begin{array}{l}\text { Cluster 1: self-acceptance of and ability to cope with } \\
\text { the illness }(3.44)\end{array}$ & $\begin{array}{l}4.41 \\
4.36 \\
4.18 \\
4.09 \\
3.95\end{array}$ & $\begin{array}{l}\text { Maintain one's sugar level } \\
\text { Accept the illness } \\
\text { Try to live as normally as possible } \\
\text { Listen to one's body and not be embarrassed about having diabetes } \\
\text { Feel good }\end{array}$ \\
\hline $\begin{array}{l}\text { Cluster 2: information about technical devices and ways } \\
\text { to finance them (3.41) }\end{array}$ & $\begin{array}{l}3.68 \\
3.59 \\
3.59 \\
3.50 \\
3.32\end{array}$ & $\begin{array}{l}\text { Receive financial aid to buy the necessary aids and devices } \\
\text { Talk to peers about diabetes to learn about the illness } \\
\text { Be assertive toward health professionals and management } \\
\text { Be well informed about new aids and therapies } \\
\text { Have insurance cover for supplies }\end{array}$ \\
\hline $\begin{array}{l}\text { Cluster 3: colleagues' and management's knowledge } \\
\text { of the illness }(3.24)\end{array}$ & $\begin{array}{l}3.86 \\
3.68 \\
3.41 \\
3.36 \\
3.00\end{array}$ & $\begin{array}{l}\text { Have colleagues that know how to react if he or she becomes unwell at work } \\
\text { Have colleagues who know he or she has diabetes } \\
\text { Inform colleagues about the possible complications of the illness } \\
\text { Have colleagues who know how to act quickly if he or she becomes ill } \\
\text { Have colleagues and management who know what diabetes is }\end{array}$ \\
\hline Cluster 4: adaptations at the workplace (3.05) & $\begin{array}{l}3.18 \\
2.95 \\
2.86 \\
2.77 \\
2.77\end{array}$ & $\begin{array}{l}\text { Have a good balance between workload and the illness } \\
\text { Be able to rearrange and plan work at own pace } \\
\text { Have a stable work content and workload } \\
\text { Monitor blood glucose levels as often as needed at the workplace } \\
\text { Have flexible workhours }\end{array}$ \\
\hline Cluster 5: ability to control diabetes at work (3.05) & $\begin{array}{l}3.27 \\
3.05 \\
2.82\end{array}$ & $\begin{array}{l}\text { Take own food to work } \\
\text { Avoid thinking too much about diabetes at work } \\
\text { Have lunch at the same time each day }\end{array}$ \\
\hline $\begin{array}{l}\text { Cluster 6: support and understanding from colleagues } \\
\text { and management }(2.64)\end{array}$ & $\begin{array}{l}2.59 \\
2.41 \\
2.14 \\
2.15\end{array}$ & $\begin{array}{l}\text { Have colleagues who understand if he or she withdraws into himself or herself } \\
\text { Have a manager that knows what diabetes is and avoid discrimination in a job } \\
\text { interview } \\
\text { Talk to the management about his or her daily condition } \\
\text { Have colleagues who keep an eye on him or her }\end{array}$ \\
\hline Cluster 7: support of health professionals (2.60) & $\begin{array}{l}3.14 \\
2.91 \\
\\
2.91 \\
\\
2.73 \\
\\
2.59\end{array}$ & $\begin{array}{l}\text { Have a supportive health professional } \\
\text { Have health professionals who can explain how to handle complications and } \\
\text { prevent them } \\
\text { Have health professionals at the company who know to react when there are } \\
\text { complications. } \\
\text { Have health professionals who treat him or her as a healthy person and not as } \\
\text { a sick person. } \\
\text { Have health professionals who tailor the treatment to the possibilities of the } \\
\text { employee }\end{array}$ \\
\hline Cluster 8: adequate benefits at work (2.27) & 3.05 & Have adequate benefits at work \\
\hline
\end{tabular}

the adaptations needed at work. The support of health professionals was reported to be particularly needed if there were medical complications. Thus employees with diabetes mellitus want to solve their problems by themselves, by learning to cope with the illness and with some support of colleagues and management.

\section{Rheumatoid arthritis}

The employees with rheumatoid arthritis produced 59 statements in response to "What an employee with rheumatoid arthritis needs to be able to keep on working is . ..." and sorted the statements into seven clusters (table 3).

The employees with arthritis assigned the highest priority to the cluster "support of management". The statements indicated that this support is important to achieve adaptations at work, such as a comfortable chair or a split-computer keyboard, flexible workhours, and possibilities for career development. Employees felt it important that their manager accepted them with rheumatoid arthritis. According to the statements in the second cluster, employees can continue to work with arthritis provided they have accepted their disease and know how to cope with it. Therefore they must be able to care of themselves, take the right medication, be aware of their capacities and limitations, participate in physical exercise, and be able to cope with pain and functional disability. The cluster "work conditions" was rated as the third most important cluster. The statements in this cluster were similar to those in the first cluster and indicated the importance of adequate facilities at the workplace. The fourth cluster, "learning from the experiences of peers" indicated the importance of learning from the experiences of other people with rheumatoid arthritis, especially in terms of how to get access to equipment and finances. "Support of colleagues, health professionals, and patient organizations" was rated as 
Table 3. What an employee with rheumatoid arthritis needs to be able to keep on working (priority score).

\begin{tabular}{|c|c|c|}
\hline Cluster & Mean & Statement \\
\hline Cluster 1: support of management (3.46) & $\begin{array}{l}4.30 \\
3.85\end{array}$ & $\begin{array}{l}\text { Management that accepts the employee with rheumatoid arthritis } \\
\text { Management that takes the needs of the employee with rheumatoid arthritis } \\
\text { into consideration } \\
\text { Management that is actively involved in the career planning of the employee } \\
\text { with rheumatoid arthritis } \\
\text { Management that helps the employee find an alternative job if the current job is } \\
\text { too demanding } \\
\text { Management that knows what the employee can and cannot do }\end{array}$ \\
\hline $\begin{array}{l}\text { Cluster 2: self-acceptance of and ablility to cope } \\
\text { with the illness (2.99) }\end{array}$ & $\begin{array}{l}3.58 \\
3.55 \\
3.32 \\
3.00 \\
3.00\end{array}$ & $\begin{array}{l}\text { Right medication in order to be less tired at work } \\
\text { Good knowledge of his or her own illness } \\
\text { Good knowledge of what his or her possibilities and limitations are } \\
\text { Healthy life-style } \\
\text { Time to practice a sport after work }\end{array}$ \\
\hline Cluster 3: work conditions (2.98) & $\begin{array}{l}3.80 \\
3.65 \\
3.65 \\
3.58 \\
3.55\end{array}$ & $\begin{array}{l}\text { Management that can provide adequate work conditions, such as a split } \\
\text { computer board or a comfortable chair } \\
\text { Freedom to spread his or her work out } \\
\text { Opportunity to work fewer hours a day } \\
\text { Opportunity to plan his or her work } \\
\text { Flexible workhours }\end{array}$ \\
\hline Cluster 4: learning from the experiences of peers (2.83) & $\begin{array}{l}2.50 \\
2.35\end{array}$ & $\begin{array}{l}\text { Opportunity to share experiences with peers } \\
\text { Knowledge of means by which costs for health supplies can be compensated }\end{array}$ \\
\hline $\begin{array}{l}\text { Cluster } 5 \text { : support of colleagues, health professionals } \\
\text { and patient organizations }(2.42)\end{array}$ & $\begin{array}{l}3.55 \\
3.30 \\
3.30 \\
3.15 \\
2.95\end{array}$ & $\begin{array}{l}\text { Organization that can help when there are conflicts between the employee and } \\
\text { management } \\
\text { Colleagues who know that the employee has rheumatoid arthritis and also what } \\
\text { he or she can and cannot do } \\
\text { Knowledge of how to explain the illness to management } \\
\text { Colleagues who do not treat the employee as sick, but instead as a healthy } \\
\text { person } \\
\text { More research about the capacities of employees with rheumatoid arthritis }\end{array}$ \\
\hline $\begin{array}{l}\text { Cluster 6: support of society (2.42) } \\
\text { Cluster 7: social climate at work (2.40) }\end{array}$ & $\begin{array}{l}3.63 \\
2.05 \\
2.40\end{array}$ & $\begin{array}{l}\text { Opportunity to work part-time and receive (part-time) disability benefit } \\
\text { Opportunity to follow education programs on how to handle the illness at work } \\
\text { Calm and friendly work environment }\end{array}$ \\
\hline
\end{tabular}

the fifth most important cluster. The statements indicated the importance of working with considerate colleagues who are aware of the consequences of having arthritis. The employees also needed to be coached regularly by health professionals at work. The clusters "support of society" and "social climate at work" were placed sixth and seventh, respectively. The sentences in the cluster "support of society" related to government policies enabling patients to receive suitable disability benefits according to their work situation.

\section{Hearing loss}

Employees with hearing loss generated 59 statements in response to "What an employee with hearing loss needs to be able to keep on working is . . . ." and grouped them into nine clusters (table 4).

The participants with hearing loss considered knowledge about hearing aids and how to pay for them as being the most important for continuing to work. The statements in the second cluster emphasized the importance of communicating the fact that they have hearing loss to colleagues. Colleagues can only take this aspect into consideration if they know that a person has a hear- ing difficulty. This situation requires specific communication skills. These skills can be acquired from peers. The next cluster stressed the importance of a person's ability to cope with hearing loss and to be assertive, qualities needed in order to stand up for one's self and to cope with difficult situations.

The statements in the fourth cluster were related to the role of occupational health physicians. They should instruct and inform employees about the different aids and devices available and the ones to which employees are entitled. The statements in the fifth cluster were related to the accessibility of hearing equipment. Hearing-loss employees need to have good hearing equipment in order to be able to communicate with others. Statements in cluster 6 indicated that employees need to be accepted and recognized by their work environment. Colleagues and management should also be aware of the possibilities and limitations of people with hearing loss and be supportive.

The next most important need was "acceptance by society". The statements in cluster 7 indicated that people with hearing impairments consider it important that society understands what their limitations are. The eighth cluster was "responsibility of management". The 
Table 4. What an employee with hearing loss needs to be able to keep on working (priority score).

\begin{tabular}{|c|c|c|}
\hline Cluster & Mean & Statement \\
\hline Cluster 1: knowledge of hearing aids and ways & 3.46 & $\begin{array}{l}\text { Awareness of the latest hearing aids and of ways to finance them } \\
\text { to finance them (3.46) }\end{array}$ \\
\hline Cluster 2: communication strategies (3.19) & $\begin{array}{l}3.46 \\
2.92\end{array}$ & $\begin{array}{l}\text { Ability to tell colleagues of hearing loss and also what the limitations of } \\
\text { hearing loss are } \\
\text { Communication strategies shared with others with hearing loss }\end{array}$ \\
\hline Cluster 3: ability to cope and be assertive (3.18) & $\begin{array}{l}4.08 \\
4.04 \\
3.38 \\
3.00 \\
3.00\end{array}$ & $\begin{array}{l}\text { Acceptance of having hearing loss } \\
\text { Assertive enough to communicate with others } \\
\text { Determined and persistent enough to ask for the needed adaptations at } \\
\text { work } \\
\text { Enough determination and courage to go on the job market } \\
\text { Sense of humor to cope with difficult situations }\end{array}$ \\
\hline Cluster 4: support of occupational physicians (3.12) & $\begin{array}{l}3.67 \\
3.63 \\
3.58 \\
3.38 \\
3.54\end{array}$ & $\begin{array}{l}\text { Occupational physicians make the needed adaptations at work quickly } \\
\text { Occupational physicians have enough knowhow about hearing loss to } \\
\text { coach well } \\
\text { One central place where people with hearing loss can go for incapacity bene- } \\
\text { fits and financial aid } \\
\text { Only people with enough knowhow about hearing loss in charge of the } \\
\text { facilities } \\
\text { Occupational physicians more specialized with hearing loss }\end{array}$ \\
\hline Cluster 5: accessibility of hearing equipment (3.10) & $\begin{array}{l}3.96 \\
3.96 \\
3.79 \\
3.29 \\
3.21\end{array}$ & $\begin{array}{l}\text { Hearing device that can help communicate better with the surroundings } \\
\text { Additional communication devices besides the hearing device } \\
\text { Knowledge of the latest hearing equipment and also of ways to finance them } \\
\text { Good patient organization } \\
\text { Education courses assessible to him or her in terms of more visual material }\end{array}$ \\
\hline $\begin{array}{l}\text { Cluster 6: consideration from colleagues and } \\
\text { management }(2.95)\end{array}$ & $\begin{array}{l}4.00 \\
3.58 \\
3.42 \\
3.38 \\
3.38\end{array}$ & $\begin{array}{l}\text { Quiet work environment } \\
\text { Colleagues who accept that he or she has hearing loss } \\
\text { Colleagues who know what it means to have hearing loss } \\
\text { Colleagues who take into consideration the limitations of an employee with } \\
\text { hearing loss } \\
\text { Recognition that having hearing loss is very tiring }\end{array}$ \\
\hline Cluster 7: acceptance by society (2.76) & $\begin{array}{l}3.88 \\
2.71 \\
2.67 \\
1.79\end{array}$ & $\begin{array}{l}\text { Recognition that the use of a hearing device does not totally overcome the } \\
\text { hearing loss } \\
\text { Job that is not tiring } \\
\text { Opportunity to exchange views with other people with hearing loss } \\
\text { Opportunity to follow courses more often than other employees in order to do } \\
\text { his or her job well }\end{array}$ \\
\hline Cluster 8: responsibility of the manager (2.56) & $\begin{array}{l}3.25 \\
2.67 \\
1.75\end{array}$ & $\begin{array}{l}\text { Possibility to claim the needed adaptations from the management directly } \\
\text { Management recognition and awareness that many people who have a } \\
\text { handicap like hearing loss want to work } \\
\text { Use of a translator when talking to people in another language }\end{array}$ \\
\hline Cluster 9: professionalization of suppliers (2.50) & 2.50 & Suppliers of hearing aids that are less commercial \\
\hline
\end{tabular}

statements in this cluster stressed that employees with hearing loss need the support of management in order to obtain the necessary adaptations and to feel at ease at the workplace.

\section{Comparison of the groups}

The concept mapping results of the three groups were compared to detect the common themes of what chronically ill employees need to continue working (table 5). The following seven common necessities were identified: "ability to cope with the illness", "support of medical professionals", "support of management", "support of colleagues", "support of society and patient organizations", "work conditions", and "facilities and benefits". Even though the priority ratings of certain ne- cessities varied between the different groups, they all need to be taken into consideration to provide adequate health care. Currently there are hardly any instruments that can be used by health professionals to identify illness-related problems at work. Therefore, on the basis of the results (common themes) of this study, a topic list was developed that can help professionals to explore work-related problems in their consultations with patients. (See the appendix.)

\section{Discussion}

Most studies on what enables people with a chronic disease to keep on working have focused on the personal and functional capacities of the employee. Our study is 
Table 5. Common themes of what employees with rheumatoid arthritis, diabetes mellitus, and hearing loss perceive to be necessary to cope at work .

\begin{tabular}{|c|c|c|c|}
\hline \multirow[t]{2}{*}{ Common themes } & \multicolumn{3}{|c|}{ Clusters within themes with ratings } \\
\hline & Rheumatoid arthritis & Diabetes mellitus & Hearing loss \\
\hline $\begin{array}{l}\text { Ability to cope with } \\
\text { the illness }\end{array}$ & $\begin{array}{l}\text { Self-acceptance and being able } \\
\text { to cope with the illness (2.99) }\end{array}$ & $\begin{array}{l}\text { Self-acceptance and control of the } \\
\text { illness at work (3.44) } \\
\text { Control of the illness at work (3.05) }\end{array}$ & $\begin{array}{l}\text { Communication strategies ( } 3.19) \\
\text { Ability to cope and be assertive (3.18) }\end{array}$ \\
\hline $\begin{array}{l}\text { Support of medical } \\
\text { professionals }\end{array}$ & $\begin{array}{l}\text { Support of colleagues and medical } \\
\text { professionals }(2.42)\end{array}$ & Support of medical professionals (2.60) & Support of occupational physicians (3.12) \\
\hline Support of management & Support of management (3.46) & $\begin{array}{l}\text { Management and colleagues with know- } \\
\text { ledge of the illness ( } 3.24) \\
\text { Support of management and } \\
\text { colleagues ( } 2.64)\end{array}$ & $\begin{array}{l}\text { Consideration from management and } \\
\text { colleagues (2.95) } \\
\text { Responsible manager (2.56) }\end{array}$ \\
\hline Support of colleagues & $\begin{array}{l}\text { Support of colleagues and medical } \\
\text { professionals (2.42) }\end{array}$ & $\begin{array}{l}\text { Management and colleagues } \\
\text { informed about the illness ( } 3.24) \\
\text { Support of management and } \\
\text { colleagues }(2.64)\end{array}$ & $\begin{array}{l}\text { Consideration from management and } \\
\text { colleagues }(2.95)\end{array}$ \\
\hline $\begin{array}{l}\text { Support of society and } \\
\text { patient organizations }\end{array}$ & $\begin{array}{l}\text { Support of society and patient } \\
\text { organizations }(2.42) \\
\text { Learning from the experiences } \\
\text { of peers ( } 2.83)\end{array}$ & & Support of society (2.76) \\
\hline Work conditions & $\begin{array}{l}\text { Work conditions (2.98) } \\
\text { Social climate at work }(2.40)\end{array}$ & Adequate work conditions (3.05) & \\
\hline Facilities and benefits & & $\begin{array}{l}\text { Access to aid devices and finance (3.41) } \\
\text { Facilities and benefits }(2.27)\end{array}$ & $\begin{array}{l}\text { Information about aid devices and } \\
\text { finance }(3.46) \\
\text { Access to hearing devices }(3.10)\end{array}$ \\
\hline
\end{tabular}

one of the few addressing this issue from the point of view of chronically ill employees themselves. Concept mapping made it possible to distinguish several conditions that the participants in the study claimed to need in order to cope at work. As is the same for all qualitative studies, the generalization of the results must be done carefully $(31,32)$ because of the limited number of participants involved, covering only three chronic conditions. Although the concept mapping sessions were organized in a consistent manner, each session had its own specific social atmosphere.

One conclusion is that employees with rheumatoid arthritis, diabetes mellitis, and hearing loss identified many common groups of factors or themes that they perceived to be important for continuing their work. Given the similarities, these results may also be applicable to other groups of chronically ill employees in The Netherlands and other industrialized countries with well-functioning labor markets and medical and social service systems. However, the different patient groups gave these themes a different priority ranking, possibly because each chronic illness is associated with specific problems and difficulties at work (eg, communication is especially important for people with hearing loss). Alternatively, the different prioritization given by the patients may reflect the difference in the health care setting in which patients receive treatment.

\section{What can health professionals learn?}

In Western industrialized countries, there is growing recognition that facilitating employment should be an important element of effective health care for the chronically ill $(33,34)$. A chronically ill employee may appear to function "normally" for a very long time and later have symptoms of burnout or chronic fatigue, problems that may be related to inappropriate work conditions. To help prevent such problems, health professionals should be able to identify them in time. Currently there are hardly any instruments available to assess work-related problems of chronically ill employees. However, the topic list that was developed in this study may be useful in this respect. Nevertheless, it should be regarded as a provisional instrument. Additional research is needed to develop it further and evaluate how it works in practice.

\section{Acknowledgments}

We thank all the participants, the Department of Rheumatology, the Department of Internal Medicine, and the Audiological Center of the Academic Medical Center of the University of Amsterdam, and also the 
Nederlandse Vereniging voor Slechthorenden, de Reumabond and the Diabetes Vereniging Nederland.

We also thank the Dutch Board of Health Insurances for funding the research and the concerted research action on "fatigue at work" granted by The Netherlands Organization for Scientific Research.

\section{References}

1. van den Bos GAM, Danner SA, de Haan RJ, Schadé E. Chronisch zieken en gezondheidszorg [Health care and chronic illnesses]. Maarssen: Elsevier gezondheidszorg; 2000.

2. Wevers CWJ, Nijboer ID, Andries F, Bloemhoff A, de Gier HG, Hildebrand VH, et al. Arbeidsmarktpositie chronisch zieken [The labour market position of chronic employees]. Zoetermeer: De Nationale Commissie Chronisch Zieken; 1993.

3. van den Bos GAM, Frijling BW, Koster-DreeseY, Schnabel P, Spreeuwenberg C. Chronisch-ziekenbeleid in de jaren negentig [Health care policies on chronically ill people]. Utrecht: SWP; 1999.

4. Buijs P, van Amstel RJ, van Dijk FJH. Dutch occupational physicians and general practitioners wish to improve cooperation. Occup Environ Med 1999;56:709-13.

5. de Buck PDM, van Amstel RJ, Buijs PC, Maasen JHW, van Dijk FJH, Hazes JMW, et al. Communication between Dutch rheumatologists and occupational physicians in the occupational rehabilitation of patients with rheumatic diseases. Ann Rheum Dis 2002;61:62-5.

6. Moerman C, Haafkens J, Schuring M, van Dijk F. Literatuurstudie: chronisch zieken en werk [Systematic review: chronic illnesses and work]. Amsterdam: Coronel Institute, AMC, University of Amsterdam; 2002.

7. Cathey MA, Wolfe F, Kleinheksel SM. Functional ability and work status in patients with fibromyalgia. Arthritis Care Res 1988; 1(2):85-98.

8. Clarke AE, Fries JF. Health status instruments and physical examination techniques in clinical measurement methodologies. Curr Opin Rheumatol 1992;4(2):145-52.

9. Leaner D, Amick BC, Rogers WH, Malspeis S, Bungay K, Cynn D. The work limitations questionnaire. Med Care 2001;39(1):72-85.

10. Mancuso CA, Paget SA, Charlson ME. Adaptations made by rheumatoid arthritis patients to continue working: a pilot study of workplace challenges and successful adaptations. Arthritis Care Res 2000;13(2):89-99.

11. Blood IM, Blood GW. Effects of acknowledging a hearing loss on social interactions. J Commun Disord 1999; 32(2):109-19.

12. SaitoY, Flores AE, Sanchez FM, Kusanagi S. The effects of communication factors on vocational adaptation of hearingimpaired workers in metro Manila. J Vocat Rehabil 1998; 11(1):75-81.

13. Hetu R, Getty L, Beaudry J, Philibert L. Attitudes towards co-workers affected by occupational hearing loss: question- naire development and inquiry. Br J Audiol 1994;28(6):299_ 311.

14. Hallberg LRM, Jansson G. Women with noise-induces hearing loss: an invisible group? Br J Audiol 1996;30(5):340-5.

15. Kyle JG, Wood PL. Vocational aspects of acquired hearing loss. Int J Rehabil Res 1985;8(4):425-34.

16. Stephens SDG, Meredith R, Callaghan DE, Hogan S, Rayment A. Early intervention and rehabilitation: factors influencing outcome. Acta Otolaryngol Suppl 1991;476:221-5.

17. Bergers J, Nijhuis F, Janssen M, van der Horst F. Employment careers of young type 1 diabetic patients in The Netherlands. J Occup Environ Med 1999;41(11):1005-10.

18. Greene DS, Geroy GD. Diabetes and job performance: an empirical investigation. Diabetes Educ 1993;19(4):293-8.

19. Roessler R, Reed C, Brown P. Coping with chronic illness at work: case studies of five successful employees. J Vocat Rehabil 1998;10(3):261-9.

20. Rumrill PD, Schoenfeld NL, Holman CA, Mullins JA. Ecological assessment of the career maintenance needs of employees with diabetes. Work 1997;9(2):111-20.

21. Polin BS. Understanding the needs of diabetics in the workplace: a clinician's perspective. Work 1997;9(2):147-55.

22. Rijken PM, Spreeuwenberg P, Baanders AN, Van Lindert H, Dekker J. Patiëntenpanel Chronisch Zieken [Panel of people with a chronic illness]. Utrecht: Nederlands Instituut voor Onderzoek van de Gezondtheidszorg; 2001.

23. Steinbrocker O, Trager CH, Batterman RC. Therapeutic criteria in rheumatoid arthritis. JAMA 1949;140:659-62.

24. Trochim MK, Linton R. Conceptualisation for evaluation and planning. Eval Program Plan 1986;9:289-308.

25. Dunn W. Public policy analysis: an introduction. Englewood Cliffs (CA): Prentice Hall; 1981.

26. Trochim MK. An introduction to concept mapping for planning and evaluation. Eval Program Plan 1989;12:1-16.

27. Weller SC, Romney AK. Systematic data collection. Vol 10. Beverly Hills (CA): Sage; 1988.

28. Kruskal JB, Wish M. Multidimensional scaling. Beverly Hills (CA): Sage, 1988.

29. Nederlands Centrum Geestelijke Volksgezondheid. Handbook concept mapping with ariadne. Utrecht: Talcott BV; 1995.

30. Southern MD, Young D, Dunt D, Appleby NJ, Batterman RW. Integration of primary health care services: perceptions of Australian general practitioners, non-general practitioner health service providers and consumers at the general practice-primary care interface. Eval Program Plan 2002;25:4759.

31. Mays N, Pope C. Rigour and qualitative research. BMJ 1995;311:109-12.

32. Boulton M, Fitzpatrick R, Swinburn C. Qualitative research in health care II: a structured review and evaluation of studies. J Eval in Clin Practice 1996; (2)3:171-79.

33. Paschkes-Bell G, Leach J, McCurdie I, Carter N. Vocational rehabilitation. BMJ 2001;323:1186.

34. British Society of Rehabilitation Medicine. Vocational rehabilitation: the way forward, London: British Society of Rehabilitation Medicine; 2001.

Received for publication: 2 September 2002 


\section{Appendix}

\section{Topic list for exploring the problems of chronically ill people at work}

Ask the patient how he or she is coping at work.

If the person is on sick leave from work, ask what kind of support he or she needs to help him or her return to work.

If the patient mentions any problems at work, explore the possible bottlenecks and solutions by using the list.

1. Self-care

- Do you have enough possibilities for self-care at work (eating regularly, taking your medication)?

- Are there any problems at work that hinder you from taking care of yourself?

2. Work conditions and aids

- Do your work conditions hinder you from working well (number of workhours, autonomy, possibility to take short breaks, worktasks and workload, workplace room and aids)?

3. Communication with management

- Is your manager aware of your condition? Does he or she know the symptoms and the effect they can have on your work?

- Do you feel comfortable talking with your manager about the adaptations you need at the workplace?

- Has your manager taken care of the adaptations you need?

4. Communication with colleagues

- Have your colleagues been told that you have a chronic illness?

- Do your colleagues know that you have a chronic illness?

- Can you talk with them about your illness and the consequences it may have for your work?

5. Communication with health professionals?

- Do you receive enough support from your occupational health physician?

- Is there enough collaboration between your general practitioner, occupational health physician, specialist, or other medical professionals?

- Do you receive enough support from your general practitioner, specialist, or other medical professionals?

- Is your treatment (medication, side effects of medication, diet, appointments with your doctor, aids) compatible with your work? 